\title{
Exploring the impact of Corporate Social Responsibility on the Financial Performance of Rural and Community Banks in Ghana
}

\author{
Reindolph Osei Anim ${ }^{1}$, Newman Amaning ${ }^{2}$, Joyce Ama Quartey ${ }^{1} \&$ Patrick Twumasi Frimpong ${ }^{3}$ \\ ${ }^{1}$ Department of Accounting and Finance, Christian Service University College, Kumasi Ghana \\ ${ }^{2}$ Department of Accountancy, Sunyani Technical University, Sunyani, Ghana \\ ${ }^{3}$ Finance Directorate, Sunyani Technical University, Sunyani Ghana \\ Correspondence: Newman Amaning, Sunyani Technical University, Sunyani, Ghana
}

Received: November 30, 2020

Accepted: December 30, 2020

Online Published: January 8, 2021

doi:10.5539/ibr.v14n2p37

URL: https://doi.org/10.5539/ibr.v14n2p37

\begin{abstract}
The interest of Rural and Community Banks (RCBs) in CSR activities which include education and leadership development, Health, Community development are geared towards ensuring the wellbeing of community members. This means that CRS is key to the success of RCBs. Based on the above reasons the study attempts to examine the influence of CSR on the financial performance of selected Ghanaian Rural and Community Banks. RCBs sampled for this study were fifteen (15) from the Kumasi Metropolis in Ghana using annual reports for a six-year-period from 2012 to 2017. Regression analysis was employed to measure the effect of CSR, financial indicators, bank age, and size of the board of directors using the Data Envelope Technique on the performance of the RCBs. Findings showed that technical efficiency and productivity were low in some RCBs over the six-year-period. The results also showed that technical change, technological change, and Total Factor Productivity affected performance. However, the size of the board of directors was inversely related to the performance of RCBs. There is therefore the need for RCBs to improve input savings and also ensure an efficient allocation of monetary resources to corporate social responsibility activities as a way of enhancing their overall productivity. Not much has been written about the impact of CSR on the financial performance of RCBs in Africa. This study thus is among the first significant attempts to explore the impacts of CSR on the financial performance of RCBs in Africa.
\end{abstract}

Keywords: rural and community banks, corporate social responsibility, corporate financial performance, data envelope analysis

\section{Introduction}

In the development of the financial system and the growth of the economy, the role banks play cannot be underestimated. It has become imperative lately that these banks should provide information on their commitments to the society, economy, and the environment in respect of their operations. In recent times banks have been involved in bridging the gap between themselves and the communities they serve, this they do through corporate social responsibility. CSR helps to improve the reputation of the bank and increase the customers' trust. (Shen, L., Govindan, K., \& Shankar, 2015)

Corporate social responsibility has become a fast and significantly emerging practice amongst financial institutions in Ghana. It is one of the newest strategies which is used by management as a means of creating a positive effect in society while business is ongoing. Sharma (2019) define CSR as the continuous commitment by an organization to ethically behave to contribute to economic development while at the same time improving the quality of life of the employees and their family members as well as the local community and society at large. Ethical decisions can be undertaken by banks to secure their banking operations through well-informed decisions which will allow government agencies to reduce their investment in the establishments. Many reasons have been advanced to explain why banks voluntarily indulge in social activities. The involvement of a firm in socially responsible activities enables its management to enhance the perceived legitimacy of the social image of a firm and set higher performance standards for the top management (Naseem, Shahzad, Asim, Rehman, \& Nawaz, 2019). However, according to Galant and Cadez (2017), accounting-based measurements are better predictors for CSR than market-based measures despite their limitations. 
Some researchers hold the view that CSR has the propensity to improve upon the competitive edge of a firm in the long run. This means that there is a positive relationship between CSR involvement and firm performance (Saeidi, Sofian, Saeidi, Saeidi, \& Saaeidi, 2015). The building of firm-specific social capital can be thought of as an insurance policy that pays off when investors and the overall economy face a severe crisis of confidence. Similarly, social capital, in addition to financial capital, can be an important determinant of firm performance, and identifies circumstances under which CSR can be beneficial for firm value. (Lins, Servaes, \& Tamayo 2017). This linkage between CSR and the financial performance of firms is at least understood area of CSR (Angelidis, Massetti and Magee-Egan, 2008).

The main driving force behind this paper is that most of the works on corporate social responsibility looked at the impact of CSR in aggregation on bank performance. However, this paper decomposes CSR into four components; Education, Community development, health, and others. The paper attempts to look at the effect of these components in isolation and then went ahead to identify the combined effect of these components on bank performance.

\section{Literature Review}

\subsection{Financial Environment Concepts}

Financial environment components consist of markets and financial institutions that serve households, business firms, and governments. These constituents can be broadly categorized into the financial system and the banking system. Owing to their similarities in the concepts of these two terminologies, they can be used in place of each other.

\subsubsection{Financial System}

The financial system is made up of building societies, banks, and credit unions, which collectively make up a network of financial institutions. The role played by this network of financial institutions through financial flows are critical in the economic development of nations. These institutions through their intermediary role assist in deploying monetary resources effectively and efficiently (Lai, 2020). Financial intermediation functions as a vessel through which monetary resources are transferred from surplus financers to deficit financiers.

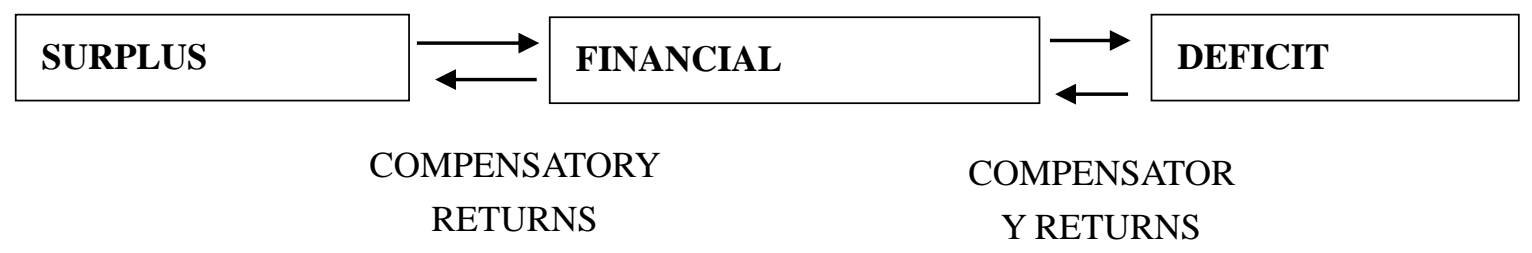

Figure 2.1. BANK FINANCIAL INTERMEDIATION

\subsection{Theoretical Framework}

Different scholars based on their academic and social exposure, prevailing interest, and their background have defined Corporate Social Responsibility (CSR) differently. CSR thus lacks a consensus definition. Additionally, these definitions are also influenced by these scholars' frame of reference. Corporate social performance and corporate conscience are synonymous with CSR. The activities performed by firms to communities, including the provision of scholarships for schooling, providing social amenities, environmental protection measures such as reafforestation, etc. are portrayed through CSR.

\subsubsection{Social Costs Theory}

According to Crane, McWilliams, Matten, Moon, \& Siegel (2008), the responsible allocation of resources is the main driving force of the effect of corporate non-economic activities on the social-economic system. The problem of modern corporate responsibility deals with the effective and efficient allocations of social costs. The literature on social cost has an indirect influence on attempts to measuring social performance. In the literature of CSR, the challenges posed by foreign markets, according to Crane, McWilliams, Matten, Moon, \& Siegel (2008), could be resolved by focusing on micro-businesses that are unique to particular communities.

\subsubsection{Agency Theory}

The concept of agency theory is an important phenomenon that goes along with shareholders-oriented values. Pepper and Gore (2015), report that the principle of agency theory has gained dominance in academic cycles 
globally within the past decade. In line with this theory, business owners are seen as principals, and the managers entrusted with the day-to-day management of the firm as agents. Accordingly, the principals are owed a fiduciary commitment by the agents. The agents are motivated by monetary and non-monetary incentives to align their interests with that of the owners. This is done to ensure goal congruence in respect of shareholders' value maximization.

\subsubsection{Stakeholder Theory}

According to the tenets of this concept, the business exists mainly for value creation for its stakeholders. Artto, Ahola and Vartiainen (2016), argue that the value creation for stakeholders is done through the conversion of the interest of business into goods and services. Werther and Chandler (2010), conclude that the conversion process serves as a medium for the coordination of the interests of stakeholders. The stakeholder model from a business perspective started its "life" as a managerial theory, the reason being that business organizations must principally have it as an aim to manage the business for the benefit of its stakeholders.

\subsubsection{Relational Theory}

The complex connection between the business and the environment is the offshoot of this theory. The kind of society determines strongly the nature of the relational theory of corporate citizenship. Business organizations take this path to behave responsibly. The fundamental principle defining this theory concerns the association firms build with their stakeholders. It is thus imperative for corporations to endlessly search for connections and relationships with their stakeholders. Maon, Lindgreen, and Swaen (2009), report that corporate citizenship is a concept that is used under integrative and political theories. Relational theory is subdivided into four theories namely; business and society, stakeholder approach, social contract, and corporate citizenship.

\subsection{Empirical Review}

Extensive studies on the link between CSR and corporate financial performance (CFP) have been carried out by several researchers. Findings from these studies show a positive, negative, or insignificant relationship between the two variables.

Prior studies (see for example Saeidi et al.,2015; Genedy \& Sakr, 2017; Inoue, Kent, \& Lee 2011) have established a positive connection between CSR and CFP. The authors established a positive but modest link between CSR and CFP after comprehensively reviewing the literature. In their quest to appreciate the aspects of CSR that the market puts a premium on, Bird, Hall, Momentè, and Reggiani (2007), found that the market values employee relations, diversity, and protection of the environment. However, in a study conducted on quoted firms on the Dow Jones Global Index, Hawn, Chatterji, and Mitchell (2018), conclude that there is an adverse connection existing between CSR and CFP. In the short run, Wang, Dou, and Jia (2016), argue that firms with weaker CSR performance achieve substantial financial performance.

\subsection{Approaches for Measuring Bank Performance}

There are two main approaches used in measuring banks' performance. They are the traditional approach that is based on accounting and referred to as the CAMEL approach and the parametric and nonparametric methods, i.e. the frontier applications.

\subsubsection{The CAMEL Approach}

In examining the performance of business units, this approach is mostly adopted. It is based on financial ratios. (Khrawish, \& Al-Sa'di, 2011). These ratios are obtained from the statement of financial positions and the annual reports of these banks. Its wide application is a result of the simplicity that comes with its calculation. According to Nguyen and Dang (2020), this model is the most popular approach approved by regulators in the banking sector who have a keen interest in estimating efficiency.

The CAMEL model stands for capital adequacy (C), asset quality management efficiency $(\mathrm{M})$, earnings quality (E), and liquidity (L). The motivation behind the use of this model lies in the probability of a bank failure in performance which would be revealed if any of the variables, whether input or output present any adverse sign. Ratios such as return on Asset (ROA), return on Equity (ROE), and net interest margin (NIM), according to Hasan, Manurung, and Usman (2020), are employed by this model. The CAMEL method ensures that the different financial health constituents of the financial institution are reviewed by using different ratios obtained and extracted from the financial statement. In the summary, a model is principally a ratio-based approach.

However, this approach presents some disadvantages. According to Bauer, Berger, Ferrier, and Humphrey (1998), these ratios do not truly indicate efficiency or performance since managers in an attempt to satisfy their interest massage these figures or ratios so to make the statements nice and attractive. They also fail to capture the 
cross-sectional differences in input and output mixes. This is because they don't take into consideration their prices. The inability of this method to control for input and output mix and other exogenous market forces has a significant adverse effect on performance. The exogenous factors have the propensity to constrain standard performance ratios by decreasing their proximity to a more perfect estimating which would account for true performance.

\subsubsection{Frontier Methods of Measuring Bank Performance}

As a result of the various criticisms and shortfalls of the CAMEL approach to estimating performance, the frontier applications have been employed to determine efficiency. It can capture the deviations that occur in the performance estimate from that of the ideas "best practice firms" on the efficient frontier. It controls the effects which occur as a result of the existence of exogenous factors like the price in the local markets. It can estimate clearly how input and output prices affect bank performance.

According to Fethi and Pasiouras (2010), frontier applications present scores that can summarize bank efficiency in a single statistic. This will help to control the difference which occurs amongst businesses in a very complex multidimensional framework that is embedded in economic theory roots. In summary, the frontier application models present a more superior analysis to that of the accounting-based ratios. It is also a better estimate of a firm's efficiency, Silva, Tabak, Cajueiro, and Dias (2017).

The parametric also known as Stochastic Frontier Approach (SFA) and non-parametric also called Data Envelope Analysis (DEA) are the two main methods used in estimating bank efficiency. This study adopts the DEA approach in estimating the efficiency of RCBs in Ghana.

\section{Methodology}

\subsection{Data}

Secondary data was used in this study. All the data were gathered from the annual financial reports, sustainability reports, and reports on CSR from the websites of the selected RCBs in Ghana. 2012 - 2017 financial years, due to their availability were used for the study. This data covered six (6) years. In sum, a panel dataset of 120 observations which was well balanced was used. Macroeconomic factors data employed in this study were collected from the website of the Ghana Statistical Service (GSS, 2014).

\subsection{Data Envelope Analysis (DEA)}

With the DEA frontier approach, the performance of each bank is evaluated by economic (cost), technical or allocative efficiency based on the assumption that the banks can convert inputs into outputs. The DEA approach is suitable for assessing banks as it possesses the capability to turn out numerous outputs from multiple inputs. Every DMU is made up of numerous inputs and outputs, which when put together, produce an overall single measure of technical efficiency. DEA as a linear programming approach in assessing efficiency can mathematically be written as.

$$
\begin{aligned}
\operatorname{Max} h & =\frac{\sum_{r} U_{r} Y_{r j o}}{\sum_{i} V_{i} X_{i j o}} \quad \text { subject to } \\
\frac{\sum_{r} U_{r} Y_{r j}}{\sum_{i} V_{i} X_{i j}} & \leq 1 \quad j=1 \ldots . n(\text { for all } j)
\end{aligned}
$$

Where the assumption is that $\mathrm{Ur}$ and $\mathrm{Vi}$ are always equal to some small positive quantity of $\varepsilon$, this helps to prevent any input or output from been ignored in the measurement and estimation of the banks' efficiency and productivity.

From the above equation if $\mathrm{h}=1$ then the DMU will be considered to be efficient. In a situation where the $\mathrm{h}<1$, then the DMU will be deemed as not efficient.

\subsection{Model Specification}

\subsubsection{First Stage Analysis: Evaluation of Rural Bank Efficiency.}

The efficiency of rural and community banks which were sampled was done by the application of the non-parametric DEA approach based on technical efficiency and productivity.

\subsubsection{Technical Efficiency}

It is derived as a maximum of the ratio of the total sum of weighted outputs to the total sum of weighted inputs. The efficiency therefore equals. 


$$
E=\frac{\text { Weighted sum of output }}{\text { weighted sum of inputs }}
$$

The weight for this ratio is derived through the limitation that related ratios for every decision-making unit should be equal to or less than one. This means a lot of inputs and outputs are lessened to a solitary "virtual" input and solitary virtual output unaccompanied by predesigned weights. In effect, the intuition is that the efficiency score is a function of the weight or the combination of inputs and outputs.

Assuming that there are ' $\boldsymbol{t}$ ' inputs and " $\mathrm{f}$ " outputs the relative technical efficiency score for a given DMU will be derived using a linear programming model as follows

$$
\begin{gathered}
\max \theta=\frac{\sum_{r=1}^{s} V_{r o}}{\sum_{i=1}^{m} V_{I} R_{i o}} \\
\text { s.t } \\
\frac{\sum_{r=1}^{s} V_{r} Y_{r j}}{\sum_{i=1}^{m} V_{I} X_{i j}} \leq 1: r \\
\mathrm{~J}=1,2--\mathrm{n} \\
V_{i} \geq 0 i ; i=1,2, \ldots \ldots . t \\
U_{i} \geq 0 i ; i=1,2, \ldots \ldots . s
\end{gathered}
$$

And $\mathrm{X}_{\mathrm{ij}}=$ quantity of input I employed by DMU $\mathbf{J}$

$\mathrm{Y}_{\mathrm{r} j}=$ quantity of output churned out by the DMU J

$$
\begin{aligned}
& V_{i}=\text { weight of input } i \\
& U r=\text { weight of output } r
\end{aligned}
$$

The Charles Cooper transformation (1962) presents the representative solution (V, U) for which

$$
\sum_{r=1}^{m} V_{i} X_{i o}=1
$$

This means that the denomination in the efficiency $\theta$ shown in the above is set equal to one. This makes the transformed linear programing model for DMU to be written as

$$
\begin{array}{cc}
\operatorname{Max} \theta= & \sum_{r=i}^{s} v_{r} y_{r o} \\
\text { s.t } & \sum_{r=i}^{s} v_{r} y_{r j}-\sum_{r=i}^{m} X_{i j} \leq 0: j=1,2, n \\
\text { and } \quad \sum_{r=i}^{m} V_{i} X_{i 0}=1 \\
\text { Where } V_{i} \geq 0: i=1,2,----m \\
u_{i} \geq 0: i=1,2,----s
\end{array}
$$


The linear programming model shown above will be run $\boldsymbol{n}$ times to identify the relative efficiency score for all the DMUs. To maximize its efficiency, select input and output that best serves the purpose. In summary, a DMU is classified efficient when it has a score of 1.00 showing $100 \%$ efficiency. On the other hand, a score of less than 1.00 shows inefficiency relatively.

\subsubsection{Second Stage Modeling}

\subsubsection{Modeling the Relationship between Bank Performance and CSR}

In the second stage, we examine the effects of CSR investment on bank performance using the IV-GMM regression

$$
y_{i t}=\alpha+\delta y_{i t-1}+\beta X_{i t}+\delta G_{t}+u_{i}+\varepsilon_{i t}
$$

Where $y_{i t}$ denotes bank performance including technical efficiency and productivity. $X_{i t}$ represents the vector of CSR investment (including community development, health, education, etc.). Whiles $G_{t}$ represents the set of macroeconomic variables. $\alpha, \beta$ and $\delta$ show the parameters to be estimated. The subscripts $i$ and $t$ represent the cross-sectional and time dimension of the panel sample respectively. $\varepsilon_{i t}$ also shows white noise and $u_{i}$ is the unobserved heterogeneity across the banks.

\subsection{Variable Selection}

The balanced panel data of 15 RCBs were used for this study. A six (6) year sample period thus from 2012 to 2017 was used. This gave 120 observations. Both bank-specific data and macro-economic variables were used for the research. To make a justified comparison with other previous research the variables were obtained from published financial statements which are highly used in published studies. It should however be noticed that the sample chosen for this research included only RCBs in the Ashanti region of Ghana.

The lists of variables used are illustrated in Tables 3.4.1 and 3.4.2 below.

Table 3.4.1. Variables and Measurements for the Second Stage Modelling

\begin{tabular}{|c|c|c|c|}
\hline Variable & Indicators & Measurement & Expected Sign \\
\hline \multicolumn{4}{|l|}{ Dependent Variable } \\
\hline \multirow[t]{2}{*}{$\begin{array}{ll}\text { Rural } & \text { Bank } \\
\text { Performance } & \end{array}$} & $\begin{array}{l}\text { Technical Efficiency } \\
(\mathrm{TE})\end{array}$ & $\begin{array}{lll}\begin{array}{l}\text { Estimated using } \\
\text { approach }\end{array} & \text { DEA-VRS } \\
\end{array}$ & + (the higher the better) \\
\hline & Productivity & $\begin{array}{lll}\begin{array}{l}\text { Estimated using } \\
\text { approach }\end{array} & \text { DEA-VRS } \\
\end{array}$ & $+($ the higher the better $)$ \\
\hline \multicolumn{4}{|l|}{$\begin{array}{l}\text { Independent } \\
\text { Variables } \\
\end{array}$} \\
\hline \multirow[t]{5}{*}{ Bank Specific Factors } & $\begin{array}{l}\text { Corporate } \quad \text { Social } \\
\text { Responsibility (CSR) }\end{array}$ & Investment on CSR & $+/-$ \\
\hline & $\begin{array}{l}\text { Non-Performing Loans } \\
\text { Ratio (NPLR) }\end{array}$ & $\begin{array}{l}\text { Ratio of Non-performing loans to } \\
\text { total loans }\end{array}$ & $+/-$ \\
\hline & Age of Bank & Age of Bank & $+1-$ \\
\hline & Firm Size & Log of Total assets & The bigger the better \\
\hline & $\begin{array}{l}\text { Investment to total assets } \\
\text { (Inv_TA) }\end{array}$ & $\begin{array}{l}\text { Ratio of the investment to total } \\
\text { asset }\end{array}$ & The bigger the better \\
\hline \multirow[t]{3}{*}{$\begin{array}{l}\text { Macroeconomic } \\
\text { Variables }\end{array}$} & $\begin{array}{l}\text { Gross Domestic Product } \\
\text { (GDP) }\end{array}$ & $\begin{array}{l}\text { Gross domestic product measured } \\
\text { at constant price }\end{array}$ & + \\
\hline & Inflation (Infl) & Annual inflation rate & - \\
\hline & Interest rate & & \\
\hline
\end{tabular}


Table 3.4.2. Variables Used in the Estimation and Measurements of Efficiency

\begin{tabular}{|l|l|}
\hline Variable & Measurement \\
\hline Output Variables & \\
\hline Total loans & Total loans and advances in GHC \\
\hline Customers Deposit & Total deposits made by customers in Ghana Cedis \\
\hline Investments & Total investments made by the banks \\
\hline Input Variables & \\
\hline Salary of Staff & Total Staff Income in Ghana Cedis \\
\hline Assets & Total assets held by banks \\
\hline Interest Expense & Net interest earnings \\
\hline
\end{tabular}

\section{Results and Discussion}

\subsection{First Stage Analysis}

4.1.1 Measurement and Benchmarking of Rural Bank Efficiency based on the DEA Approach

Table 4.1. Technical efficiency - variable returns to scale

\begin{tabular}{|c|c|c|c|c|c|c|c|c|}
\hline DMU & 2012 & 2013 & 2014 & 2015 & 2016 & 2017 & Mean & Rank \\
\hline 1 & 0.891 & 0.824 & 0.927 & 1 & 1 & 1 & 0.940 & 11th \\
\hline 2 & 0.817 & 0.874 & 1 & 1 & 0.944 & 1 & 0.939 & 12 th \\
\hline 3 & 0.901 & 0.964 & 0.876 & 0.978 & 1 & 1 & 0.953 & 9th \\
\hline 4 & 1 & 1 & 0.876 & 1 & 1 & 0.985 & 0.977 & 7th \\
\hline 5 & 1 & 1 & 1 & 1 & 1 & 1 & 1 & $1 \mathrm{st}$ \\
\hline 6 & 1 & 1 & 0.958 & 0.953 & 1 & 1 & 0.985 & 6 th \\
\hline 7 & 1 & 1 & 1 & 1 & 1 & 1 & 1 & $1 \mathrm{st}$ \\
\hline 8 & 1 & 0.955 & 0.645 & 0.782 & 0.749 & 0.821 & 0.825 & 14th \\
\hline 9 & 0.751 & 0.721 & 1 & 0.85 & 0.923 & 0.909 & 0.859 & 13th \\
\hline 10 & 1 & 0.994 & 0.883 & 0.855 & 0.918 & 1 & 0.941 & 10th \\
\hline 11 & 0.788 & 0.758 & 0.73 & 0.834 & 0.853 & 0.955 & 0.819 & 15 th \\
\hline 12 & 1 & 1 & 1 & 1 & 1 & 1 & 1 & $1 \mathrm{st}$ \\
\hline 13 & 1 & 1 & 1 & 0.946 & 1 & 1 & 0.991 & 5 th \\
\hline 14 & 1 & 1 & 1 & 1 & 1 & 1 & 1 & $1 \mathrm{st}$ \\
\hline 15 & 1 & 1 & 1 & 0.883 & 1 & 0.961 & 0.974 & 8 th \\
\hline Mean & 0.943 & 0.939 & 0.926 & 0.939 & 0.959 & 0.975 & 0.947 & \\
\hline
\end{tabular}

The first stage of the study presented the DEA efficiency frontier which calculated the technical efficiency for each chosen rural bank for the period under study.

Table 4.1 presents the results of the DEA efficiency scores. The results show that the overall average technical efficiency score is $94.7 \%$. The implication is that the sampled rural banks have a $5.3 \%$ level of inefficiency in input usage. They can therefore obtain input savings of 5.3\%. DMUs with an efficiency score of 1 are described as technically efficient. The annual technical efficiency scores showed that generally some of the selected rural banks are performing better in technical efficiency more than others as in the case of DMU 5, 7, 12, and 14. The DMUs with an efficiency score less than 1 are technically inefficient as in the case of 1, 2, 3 4, 6, 8, 9, 10, 11, 13 , and 15 . The most inefficient banks are 8, 9, and 11: require input savings of $17.5 \%, 14.1 \%$, and $18.1 \%$ respectively. The least inefficient banks are 4, 15, and 13: requiring input savings of 2.3\%, 2.6\%, and 0.9\% respectively. DMUs 1 and 2 can obtain input savings of $6 \%$. and $6.1 \%$ respectively. In summary, technically inefficient DMUs need input savings according to their level of inefficiency in input usage. 


\subsubsection{Analysis of Productivity of Selected Rural Banks}

The productivity results of DEA for the sampled RCBs are shown and discussed in this section. A summary of the annual performance is also presented to portray the trend over the study period. Table 4.2 shows the summarized form of the estimates of productivity changes as well as the components for each bank in the study period.

Table 4.2. Malmquist Index Summary of Annual Means

\begin{tabular}{|r|r|r|r|r|r|}
\hline & \multicolumn{1}{l|l}{ effch } & \multicolumn{1}{l|}{ lechch } & \multicolumn{1}{l|}{ pech } & \multicolumn{1}{l|}{ lech } & \multicolumn{1}{l|}{ Tfpch } \\
\hline $2012 / 2013$ & 1.018 & 0.912 & 0.995 & 1.023 & 0.929 \\
\hline $2013 / 2014$ & 0.984 & 0.992 & 0.984 & 1 & 0.976 \\
\hline $2014 / 2015$ & 0.999 & 1.115 & 1.018 & 0.981 & 1.113 \\
\hline $2015 / 2016$ & 1.041 & 0.887 & 1.022 & 1.018 & 0.922 \\
\hline $2016 / 2017$ & 1.022 & 0.922 & 1.019 & 1.003 & 0.942 \\
\hline Grand (2012-2017) & 1.013 & 0.962 & 1.007 & 1.005 & 0.974 \\
\hline
\end{tabular}

The above table shows the determinants of productivity. These are efficiency change (effch), technical change (techch), pure efficiency change (pech), scale efficiency change(sech) and total factor of productivity change (tfpch)

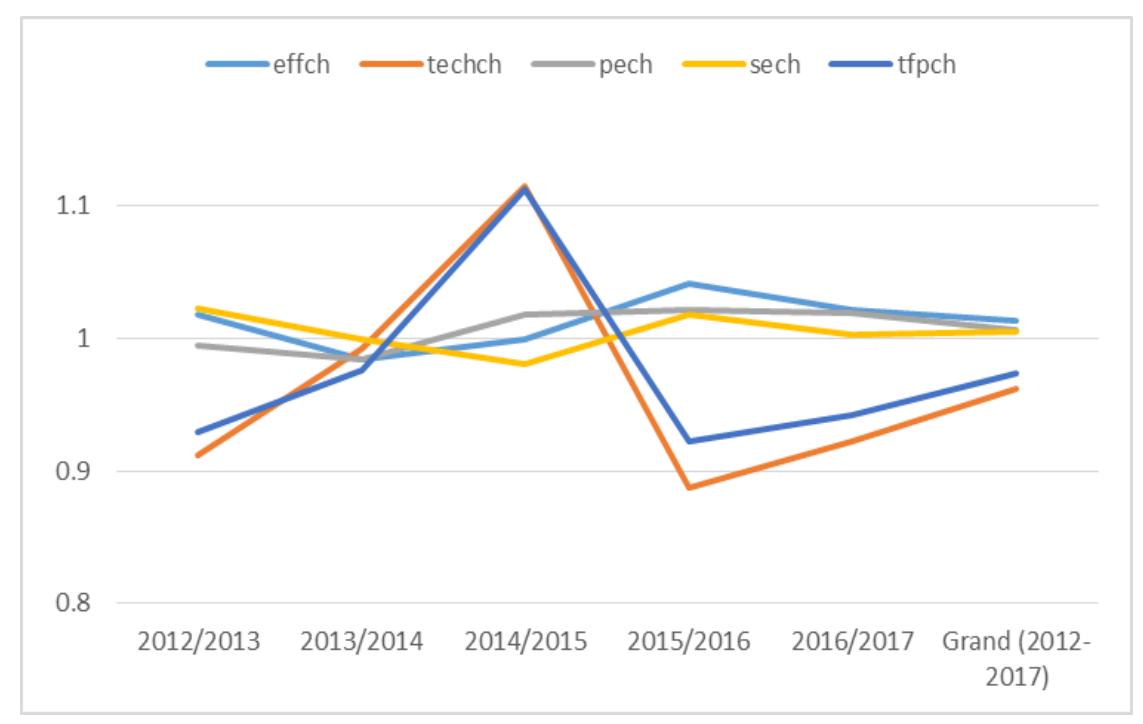

Figure 4.1. Annual means of productivity components

Primarily, out of the 15 banks sampled, only five (5) were seen to show technological improvement. These are banks $2,3,4,5$, and 12 . These banks had scores greater than 1 . The remaining 10 exhibited technological regress as shown in their scores. They had scored less than 1. Again eight (8) of the selected banks representing 53.3\% understudy suffered productivity decline ranging from $-0.21 \%$ to $-0.26 \%$. This reduction in productivity was a result of technological regress. It can also be seen that productivity grew from $0.14 \%$ to $0.4 \%$. The observations in scale efficiency also showed that six (6) out of the sampled banks were scaling inefficient. This was manifested in their low productivity levels. The main source of productivity decline was pivoted on technological inefficiency and technological regress. Only a few of the banks exhibited both scale and technological efficiency. Bank 3 had the highest improvement in terms of productivity representing a growth rate of $0.12 \%$. Bank 14 had the highest productivity decline of $-0.26 \%$ 


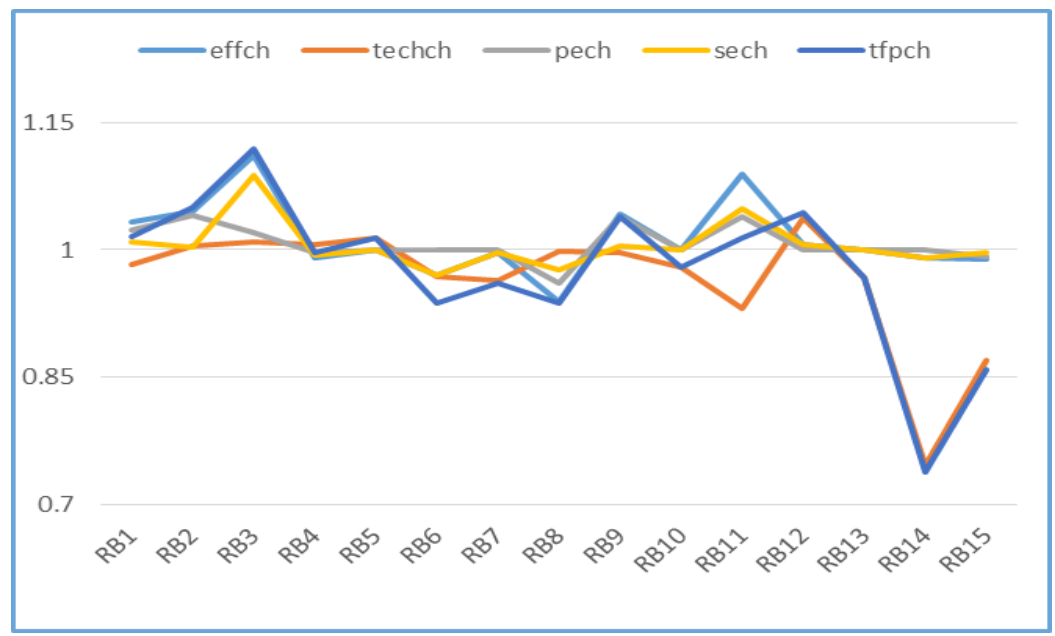

Figure 4.2. Overall summary of firm means of productivity estimates

Table 4.3. Frequency Distribution of TFP, TECH, EFFCH, PECH and SECH

\begin{tabular}{llllllllllll}
\hline EFFCH & Freq. & $\mathbf{\%}$ & TECH & Freq. & $\mathbf{\%}$ & TFP & Freq. & $\mathbf{\%}$ & PECH & Freq. & \% \\
\hline$<\mathbf{1}$ & 6 & 40 & $<\mathbf{1}$ & 10 & 66.67 & $<\mathbf{1}$ & 8 & 53.3 & $<1$ & 3 & 20 \\
$\mathbf{1}$ & 3 & 20 & $\mathbf{1}$ & 0 & 0 & $\mathbf{1}$ & 0 & 0 & $=1$ & 7 & 46.67 \\
$>\mathbf{1}$ & 6 & 60 & $>\mathbf{1}$ & 5 & 33.33 & $>\mathbf{1}$ & 7 & 46.67 & $>1$ & 5 & 33.33 \\
\hline Total & $\mathbf{1 5}$ & $\mathbf{1 0 0}$ & Total & $\mathbf{1 5}$ & $\mathbf{1 0 0}$ & Total & $\mathbf{1 5}$ & $\mathbf{1 0 0}$ & Total & $\mathbf{1 5}$ & $\mathbf{1 0 0}$ \\
\hline
\end{tabular}

\subsubsection{DEA Total Factor Productivity Changes (TFP) Summary of Annual Means}

\subsubsection{Total Factor Productivity Changes}

This section of the study provides the outcomes for the total factor productivity changes (TFP), that is equivalent to the product of EFFCH (Efficiency change) and TECH (technical change). Observation from the table portrays that TFP was on the decline mostly in the years of 2012-2013, 2013-2014, 2015-2016, and 2016-2017. This shows that productivity is on the decline in between these years. TFP however improved between the years of 2014-2015. This means that in between these periods, there was an improvement in technological and efficiency changes. The overall TFP experienced a deterioration of $-0.78 \%$. The deterioration in TFP is however not a surprise owing to the presence of technical regress. Attributable to this discovery is a result of the seasonal changes in the banking industry in Ghana. Fundamental to this issue is that banks operating technology is season-specific.

\subsubsection{Overall Change of TFP for the Study Period}

The additional analysis presents the overall change of TFP for the study period. This helps to make a better comparison of the endpoint's years from the first period which is 2012-2013. As presented in the appendix, the results augment the initial observation that productivity declined during the period. In cumulative terms, there was a $-14.4 \%$ reduction in TFP during the study period for the sampled RCBs. The rural banks employed $11.8 \% \%$ more inputs in 2016-2017 relative to 2012-2013. In cumulative terms, technological change showed a regress of $-8.8 \%$ between 2012-2013. The accumulative trends for technological change show a regress (inward shift of the frontier) of $-9.6 \%$ between 2013 and 2014. The cumulative technical efficiency, on the other hand, depicts progress (efficiency catch-up) of $0.2 \%$. Impliedly, this principle depicts that whereas relatively less technically-efficient RCBs did catch-up with more technically-efficient ones in some years; they were still uneconomical using relatively more inputs in production. They were thus, unable to provide the same level of efficient services.

\subsection{Second Stage Analysis}

\subsubsection{Modeling the Relationship between Bank Performance and CSR}

In the second stage, we examine the effects of CSR investment on bank performance using the IV-GMM regression. The study critically examines the impact of CSR expenditure on rural bank performance over the sample period. The study explored the specific CSR components as well as other financial and non-financial 
variables. Macro-economic factors were also employed to determine bank performance. The two-step GMM estimator approach is used to do the estimations. The outcomes of the estimations are presented in Tables 4.5 and 4.6. The study examines the impact of CSR expenditure on technical efficiency and productivity.

The first estimation is made up of two models that are interconnected. Model 1 focuses on the overall CSR investment. The estimation of model 1 is not only to explore the total CSR expenditure effects on technical efficiency but to also make a comparison of the current study to extant studies that have been mainly based on Technical efficiency.

Model two captures the various components of CSR investment and how they affect technical efficiency. This shows that the values were added hierarchically. This will help to track any problems concerning collinearity as they have the propensity of affecting the signs of the parameters which will consequently churn out inconsistent results. To solve the problem of any potential biases, the standard errors of the models were rectified using the Windmeijer (2005) finite sample correction. The instrument's validity in the system was checked using Sargan tests.

Table 4.5. Technical Efficiency: Dependent Variable

\begin{tabular}{lcc}
\hline & Technical Efficiency: Dependent Variable & \\
\cline { 2 - 3 } Variables & MODEL 1 & MODEL 2 \\
\hline LnCSR & $.092(.042)^{* * *}$ & $-.037(.186)^{*}$ \\
Lneducation & & $-.289(.157)^{*}$ \\
Lncomdev & & $-.292(.077)^{* * *}$ \\
Lnhealth & & $.081(.083)$ \\
Lnother & $-.008(.0181)$ & $-.105(.320)$ \\
Lndcp & $-.147(.066)^{* *}$ & $-.056(.103)$ \\
Lnage & $-.104(.042)^{* *}$ & $-.369(.533)$ \\
Npl & $-.008(.0181)$ & $.135(.445)$ \\
Lnroa & $-.147(.066)^{* *}$ & $-.369(.533)$ \\
Liability & $-.008(.0181)$ & $.135(.445)$ \\
Department & $-.147(.066)^{* *}$ & $.064(.168)$ \\
Duality & $-.104(.042)^{* *}$ & $3.941(3.520)$ \\
Size & $-.008(.0181)$ & $-.369(.533)$ \\
Females & $-.147(.066)^{* *}$ & $.135(.445)$ \\
Constant & & \\
\hline Diagnostic Test & 36.53 & 36.53 \\
Chi-Square Value & 0.0000 & 0.000 \\
Prob>Wald Chi ${ }^{2}$ & 120 & 120 \\
Nos. Observations & 120 \\
\hline
\end{tabular}

$*, * *, * * *$ denotes coefficients significant at $10 \%, 5 \%$ and $1 \%$

\subsubsection{Bank Specific Factors and Technical Efficiency}

Model 1 focuses on the bank-specific factors. It showed that overall CSR investment affects performance. Corporate Social Responsibility is the bedrock on which community commitment to an organization hinge (Lorizio \& Gurrieri (2019). It gives corporate organizations a competitive advantage in the market. This means that banks that perform CSR activities have a strong customer base and so they can generate a lot of returns on their investment leading to an improvement in Technical Efficiency (Xie, Nozawa, Yagi, Fujii, \& Managi (2019). These findings support Saeidi et al. (2015) in their research on the impact of corporate social responsibility on firm performance. The results also show that other bank-specific factors like the age of the bank, non-performing loans, and growth in liabilities had a detrimental effect on technical efficiency (Waqas, Fatima, Khan, \& Arif ,2017). This also confirms the learning curve hypothesis which posits that as bank gains experience over time, they can reduce waste as it learns lessons from past experiences, best practices in the industry to make informed decisions in the future. This helps to reduce risks and losses (Musaji et al., 2019).

\subsubsection{Bank Liabilities and Technical Efficiency}

It can also be seen that growth in liabilities has a statistically negative effect on technical efficiency. Growth in liabilities means that banks are earning less on assets. They take more deposits without using the funds to raise loans which will help them to increase their net interest income (Tesfai, 2015). Non-performing loans also harmed technical efficiency. A non-performing loan is a parameter for measuring credit quality. High NPLs means most of the banks are developing hardcore on their loan accounts (Ghosh, 2015). This therefore means 
these banks have loan accounts which are static and not diminishing in the outstanding balance as a result of the non-payment of interest and principal. These findings collaborate with Tesfai 2015, who found a negative relationship between non-performing loans and performance.

\subsubsection{Duality and Technical Efficiency}

Duality was also statistically related to technical efficiency. Most of the Board members of these RCBs were found to be the managing directors of the banks. This made it difficult for them to separate ownership from Management. In effect they were not able to work efficiently through proper supervision and monitoring of banks' liabilities and their conversions into loans or assets. The size of the bank also had a negative relationship with Technical efficiency. This could be a result of poor monitoring and work specialization. Most of the workers were assigned to so many tasks hence they could not get use to one particular type of task to enhance specialization. This reduces overall performance. This supports the findings of Tower and Alkadry (2008), and (Waqas et al (2017).

\subsubsection{Components of CSR and Technical Efficiency}

In Model 2, It can be seen that Investment in Education and community development had a negative relationship with technical efficiency. However, the impact was statistically not significant. This means that an increase in education and community development investments do not result in a reduction of technical efficiency. However, expenditure on health had a strong negative and statistically significant effect on technical efficiency.

Table 4.6. Bank Productivity Indices: Dependent Variable

\begin{tabular}{|c|c|c|c|}
\hline \multicolumn{4}{|c|}{ Bank Productivity Indices: Dependent Variable } \\
\hline Variables & MODEL 1 & MODEL 2 & MODEL 3 \\
\hline Lneducation & $-0.0484(0.153)^{*}$ & $-0.14171(0.156) *$ & $-0.1637(0.174) *$ \\
\hline Lncomdev & $-0.1228(0.091) * *$ & $0.002877(0.093) * *$ & $0.011235(0.104) *$ \\
\hline Lnhealth & $0.333705(0.157) *$ & $0.185414(0.159) *$ & $0.205496(0.178) *$ \\
\hline Lnother & $0.039647(0.085) * *$ & $0.060423(0.086) * *$ & $0.077862(0.097) * *$ \\
\hline Lndcp & $0.828081(1.054) *$ & $2.15821(1.068) *$ & $1.725251(1.197) *$ \\
\hline Lnage & $18.98316(8.629) *$ & $26.39514(8.740) *$ & $24.54861(9.788) *$ \\
\hline $\mathrm{Npl}$ & $-2.80991(1.352) *$ & $-4.07505(1.369) *$ & $-3.70605(1.533) *$ \\
\hline Lnroa & $0.331699(0.239) *$ & $0.408674(0.242) *$ & $0.448688(0.271) *$ \\
\hline Liability & $-0.59651(0.389) *$ & $-0.94579(0.394) *$ & $-0.88793(0.441) *$ \\
\hline Department & $0.062013(0.107) *$ & $0.066258(0.108) *$ & $0.038073(0.121) *$ \\
\hline Duality & $-0.11837(0.129) *$ & $-0.16224(0.130) *$ & $-0.18714(0.145) *$ \\
\hline Size & $\begin{array}{l}-0.01651(0.047) \\
* * *\end{array}$ & $-0.02396(0.048) * * *$ & $-3.33 \mathrm{E}-02(0.054) * *$ \\
\hline Females & $-0.08529(0.085) * *$ & $-0.08171(0.087) * *$ & $-8.54 \mathrm{E}-02(0.097) * * *$ \\
\hline Constant & $-22.1827(9.545) *$ & $-28.2819(9.660) *$ & $-26.2575(10.815) *$ \\
\hline \multicolumn{4}{|l|}{ Diagnostic Test } \\
\hline Chi-Square & 0.6629 & 0.7926 & 0.9995 \\
\hline Prob $>$ Wald $\mathrm{Chi}^{2}$ & 0.0000 & 0.000 & 0.000 \\
\hline Nos. Observations & 64 & 64 & 64 \\
\hline
\end{tabular}

$*, * *, * * *$ denotes coefficients significant at $10 \%, 5 \%$ and $1 \%$

The second stage of analysis is the estimation of the determinants of bank productivity which are Technical change, Technological Change, and Total factor productivity.

\subsubsection{Technical Change and CSR Variables}

In model 1, Technical change is regressed against the CSR variables which are community development, Health, Education, and miscellaneous activities. The purpose is to determine the extent to which these variables affect bank productivity.

\subsubsection{Technical Change and Education}

From the results, it can be seen that education has a negative but statistically insignificant effect on technical change. This implies that an increase in expenditure on education does not statistically affect the Technical change. This could be that expenditure in education is so important to community folks such that they build a strong bond and loyalty with the bank. This might have increased the customer base of the banks leading to larger deposits which creates large assets for the bank. This however rejects the findings of (Lorizio \& Gurrieri, 2019) who revealed that CSR expenditure significantly affects bank productivity as a result of the reduction in 
shareholder value.

\subsubsection{Technical Change and Community Development}

It is however interesting to note that expenditure on community development had a slightly statistically significant but inverse relationship with bank technical efficiency change. This implies that community development may not affect the rural community members directly. Rural community development is perceived to be a public good and therefore it does not create a strong commitment and loyalty with bank customers. Another observation is that investments in community developmental activities are normally in fixed assets which generally may not increase shareholder value. These findings support the work of Uwalomwa and Egbide (2012) who found a statistically significant negative relationship between CSR expenditure and bank productivity.

\subsubsection{Technical Change and Health}

Other findings reveal that investment in health activities had a positive and significant relationship with bank productivity. These health activities are essentially blood screening, the building of hospitals, and payment of hospital charges. These are seen as a very vital project which creates strong customer relations with depositors. This helps to increase the customer base thereby generating higher deposits which invariably creates an asset for the banks through loans. This supports the work of Maqbool and Zameer (2018), who revealed that CSR expenditure helps to create a competitive advantage for banks who involve themselves in CSR activities.

\subsubsection{Technological Progress and CSR Variables}

Model 2 is the estimation of CSR investment on the technological progress of the banks. Technological progress is one of the indices which measure bank productivity. It is the development, achievement in the overall process of invention, innovation as well as diffusion of technology or processes.

\subsubsection{Technological Progress and Community Development}

The results show that investments in Community development and other miscellaneous activities have a positive and somewhat significant relationship with technological change. Thus, an increase in these expenditures will lead to an increase in bank technological change.

\subsubsection{Technological progress and education}

It is also interesting to note that expenditure on education is negatively related to technological change. An increase in expenditure on education leads to a decrease in technological change. However, the p-value of $15.6 \%$ suggests that the effect is not very significant. This proves that expenditure on education may be so high but banks are compensated by an increase in customer loyalty. This will help the bank to raise enough funds to invest in technology.

\subsubsection{Technological Progress and Health}

Investment in health activities had a positive and significant relationship with bank productivity. These health activities are essentially blood screening, the building of hospitals, and payment of hospital charges. These are seen as a very vital project which creates strong customer relations with depositors. This helps to increase the customer base thereby generating higher deposits which invariably creates an asset for the banks through loans. This supports the work of Maqbool and Zameer (2018), who revealed that CSR expenditure helps to create a competitive advantage for banks who involve themselves in CSR activities

\subsubsection{Total Factor Productivity (TFP) and CSR variables}

Model 3 estimates the effect of CSR investment in Total Factor Productivity (TFP). It can be seen that investments in community development and health have a positive and significant effect on TFP. This is essential because customer's deposits are liabilities for the banks, however, they are the cheapest source of funds which the bank can use to create assets and earn interest income. This means that banks will have an increase in Net Interest Income as well as a higher percentage of Net Interest Margin. This will significantly increase bank productivity in terms of shareholder wealth maximization. These findings corroborate the works of Carlson and Akerston (2008) who found a positive and significant relation between CSR involvement and Total Factor Productivity. Expenditure on education was negatively related to bank productivity, however, the effect is not statistically significant. This implies that the huge capital outflow from the banks is compensated through an increase in deposits which create investment returns to the banks through the disbursement of loans and advances. This work empirically confirms the findings of Ojo (2008) that the relationship between CSR and TFP is not significant as shown by the p-value of $9.7 \%$ 


\subsection{Discussion of Results}

The main objective of the study is to find out the effect of corporate social responsibility on the performance of RCBs in Ghana, particularly in the Ashanti region. Again, the study seeks to find out the impact of the CSR components on the indices of bank productivity which are technical change, technological change, and Total Factor Productivity. A total of 15 rural banks out of twenty-five (25) rural banks in the Ashanti region were sampled representing $60 \%$ of the entire population. Financial data were obtained from the annual reports of the bank for the periods of 2012-2017. Rural bank performance was evaluated from two main dimensions namely; technical efficiency and bank productivity using the widely used non-parametric DEA approach. The main reason for focusing on rural banks stems from the fact that these banks contribute significantly to economic growth and development. However, their operations are saddled with a lot of threatening challenges which invariably have a negative bearing on their sustainability. Additionally, these challenges affect their ability to perform their core functions. It is therefore expedient if not indispensable to identify these challenges and how they affect their productivity and then devise strategies to resolve them.

The findings of the study showed that the most of sampled rural banks were underperforming in respect of technical efficiency. The DEA efficiency revealed that the overall average technical efficiency score is $94.7 \%$. The implication is that the sampled rural banks have a 5.3\% level of inefficiency in input usage. They can therefore obtain input savings of 5.3\%. DMUs with an efficiency score of 1 are described as technically efficient. The annual technical efficiency scores also show that generally some of the selected rural banks are performing better in technical efficiency more than others as in the case of DMU 5, 7, 12, and 14. The DMUs with an efficiency score less than 1 are technically inefficient as in the case of 1,2,34, 6, 8, 9, 10,11,13, and 15 . The most inefficient banks are 8,9 , and 11 : require input savings of $17.5 \%, 14.1 \%$, and $18.1 \%$ respectively. The least inefficient banks are 4 , 15, and 13: requiring input savings of 2.3\%, 2.6\%, and 0.9\% respectively. DMUs 1 and 2 can obtain input savings of $6 \%$ and $6.1 \%$ respectively. This means that technically inefficient DMUs need input savings according to their level of inefficiency in input usage.

Concerning bank productivity, by focussing on the bank-specific factors the research showed that overall CSR investment affects performance. Corporate Social Responsibility is the bedrock on which community commitment to an organization hinge on. It gives corporate organizations a competitive advantage in the market. This means that banks that perform CSR activities have a strong customer base and so they can generate returns on their investment leading to an improvement in Technical Efficiency. These findings support (Waqaset al., 2017) in his research on the impact of corporate social responsibility on firm performance.

The results also show that other bank-specific factors like the age of the bank, non-performing loans, and growth in liabilities harmed technical efficiency. This confirms the learning curve hypothesis which posits that as bank gains experience over time, they can reduce waste as it learns lessons from past experiences, best practices in the industry to make informed decisions in the future. Growth in liabilities was also on the high side meaning that banks are earning less on assets. They take more deposits without using the funds to raise loans which will help them to increase their net interest income (Tesfai, 2015). Non-performing loans also harmed technical efficiency. A non-performing loan is a parameter for measuring the credit quality, this means high NPLs arise as a result of the banks developing hardcore on their loan accounts. This, therefore, means these banks have loan accounts which are static and not diminishing in the outstanding balance as a result of the non-payments of interest and principal. These findings collaborate with Batir, Volkman, and Gungor (2017) who found a negative relationship between non-performing loans and performance.

Again, Duality was also seen to affect bank productivity. Most of the Board members of these RCBs were found to be the managing directors of the banks. This meant that it was practically impossible to separate ownership from Management. In effect, they were not able to work efficiently through proper supervision and monitoring of banks' liabilities and their conversions into loans or assets. The size of the bank also had a negative relationship with Total Factor Productivity. This is a result of poor monitoring and work specialization. Most of the workers are assigned to so many tasks hence they don't stick to one particular type of task to enhance specialization. This reduces overall performance. This supports the findings of Tower and Alkadry, 2008; and Waqaset al., 2017.

From the results, it can be seen that bank productivity has a negative but statistically insignificant effect on education. This implies that an increase in expenditure on education does not statistically affect the banks' productivity. Primarily expenditure in education is so important to community folks such that they build a strong bond and loyalty with the bank. This might have increased the customer base of the banks leading to larger deposits which creates large assets for the bank. This however rejects the findings of Lorizio and Gurrieri (2019), who revealed that CSR expenditure significantly affects bank productivity as a result of the reduction in 
shareholder value.

It can be seen that investments in community development and health have a positive and significant effect on TFP. This is essential because customer's deposits are liabilities for the banks, however, they are the cheapest source of funds which the bank can use to create assets and earn interest income. This means that banks will have an increase in Net Interest Income as well as a higher percentage of Net Interest Margin. This will significantly increase bank productivity in terms of shareholder wealth maximization. These findings corroborate the works of Carlson and Akerston (2008) who found a positive and significant relation between CSR involvement and Total Factor Productivity. However, expenditure on education was negatively related to bank productivity.

\section{Conclusions and Recommendations}

\subsection{Conclusions}

The main objective of the research was to examine the effect of CSR investments on rural bank performance in the Ashanti Region of Ghana. The performance was measured from the dimensions of technical efficiency and bank productivity. There is a general assumption that economic growth and development are pivoted on bank performance. Therefore, the estimation of the performance of these banks is of critical concern to investors, managers, regulators, and policymakers. As a result of the empirical nature of the work, there was a need to have a comprehensive understanding of the banking system in Ghana.

The Data Envelope Technique approach was used in measuring technical efficiency and productivity. The study concentrated on a sample of 15 banks out of 25 RCBs in the Ashanti region from 2012-2017.

In aggregate terms, the findings of the study depict that the most of sampled rural banks were underperforming in respect of technical efficiency. The DEA efficiency revealed that the overall average technical efficiency score is $94.7 \%$. The implication is that the sampled rural banks have a 5.3\% level of inefficiency in input usage. They can therefore obtain input savings of 5.3\%. DMUs with an efficiency score of 1 are described as technically efficient. The annual technical efficiency scores also show that generally some of the selected rural banks are performing better in technical efficiency more than others as in the case of DMU 5, 7, 12, and 14. The DMUs with an efficiency score less than 1 are technically inefficient as in the case of $1,2,34,6,8,9,10,11,13$, and 15 . The most inefficient banks are 8, 9, and 11: require input savings of $17.5 \%, 14.1 \%$, and $18.1 \%$ respectively. The least inefficient banks are 4,15 , and 13: requiring input savings of $2.3 \%, 2.6 \%$, and $0.9 \%$ respectively. DMUs 1 and 2 can obtain input savings of $6 \%$ and $6.1 \%$ respectively. This means that technically inefficient DMUs need input savings according to their level of inefficiency in input usage.

\subsection{Recommendations}

In aggregate terms, the findings of the study depict that the most of sampled rural banks were underperforming in respect of technical efficiency and productivity. This means that there is more room for improvement for the RCBs in terms of their technical efficiency and productivity. The findings also portray that collectively Technical change; Technological change and Total Factor productivity need improvements in terms of efficient allocation of monetary resources to CSR activities. To give a road map to better performance, the findings provide critical policy implications for individual RCBs as well as their industry stakeholders (regulators) to improve the technical efficiency of these RCBs if they need to excel in undertaking their core mandates. Recommendations can be deduced from the findings in that, RCBs should improve their technical efficiency by reducing wasteful operations so they can undertake decisions that will be in the interest of the bank. This will help in leading to an improvement in technical efficiency as well as productivity of the banks. These RCBs must improve upon their efforts in generating non-interest income through commissions, net-earnings from the issuance of investment instruments as they would make a significant contribution to the productivity of RCBs.

\subsection{Limitations of the Study}

The research was carried out irrespective of the limitations. The work was carried out for a six-year period from 2012-2017. Therefore, any developmental trends which might occur before or after this period present a limitation. Another limitation is the availability of time where there is the need for a thorough and a comprehensive study. The time available was not adequate. Additionally, inadequate funds limited the research because of various expenses that was directly and indirectly incurred form the research.

\subsection{Policy Implications}

This study will help the managers of RCBs to understand that their involvement in societal activities can help in the management of social risk exposures as part of their main operations. This study will also help the 
management of RCBs to understand better ways of institutionalizing good marketing policies and strategies for the bank. It will also help RCBs to attract, motivate, and retain competent employees who will assist them in achieving then state objectives.

It is also worth mentioning that rural banking performance depends largely on the availability and accessibility of credit to their clients. The rampant collapse of rural banks in the 1990s coupled with the high rate of insolvency and liquidity issues of RCBs is a major challenge that has become eminent in the financial sector. This research finding will serve as a yardstick to ascertain the effectiveness of actions, which hitherto were used to address the issues regarding the technical efficiency and productivity of rural banks. Also, the findings of this study will assist managers of these rural banks under review to effectively offer their performance against their target and the standards set by Central Banks.

\section{References}

Angelidis, J. P., Massetti, B. L., \& Magee-Egan, P. (2008). Does corporate social responsibility orientation vary by position in the organizational hierarchy? Review of Business, 28(3), 23.

Artto, K., Ahola, T., \& Vartiainen, V. (2016). From the front end of projects to the back end of operations: Managing projects for value creation throughout the system lifecycle. International Journal of Project Management, 34(2), 258-270. https://doi.org/10.1016/j.ijproman.2015.05.003

Batir, T. E., Volkman, D. A., \& Gungor, B. (2017). Determinants of bank efficiency in Turkey: Participation banks versus conventional banks. Borsa Istanbul Review, 17(2), 86-96. https://doi.org/10.1016/j.bir.2017.02.003

Bauer, P. W., Berger, A. N., Ferrier, G. D., \& Humphrey, D. B. (1998). Consistency conditions for regulatory analysis of financial institutions: a comparison of frontier efficiency methods. Journal of Economics and business, 50(2), 85-114. https://doi.org/10.1016/S0148-6195(97)00072-6

Bird, R., Hall, A. D., Momentè, F., \& Reggiani, F. (2007). What corporate social responsibility activities are valued by the market? Journal of business ethics, 76(2), 189-206. https://doi.org/10.1007/s10551-006-9268-1

Carlsson, J., \& Åkerstöm, R. (2008). Corporate Social Responsibility: a case study of Öhrlings PricewaterhouseCoopers.

Crane, A., McWilliams, A., Matten, D., Moon, J., \& Siegel, D. S. (Eds.). (2008). The Oxford handbook of corporate social responsibility. Oxford University Press on Demand. https://doi.org/10.1093/oxfordhb/9780199211593.003.0001

Fethi, M. D., \& Pasiouras, F. (2010). Assessing bank efficiency and performance with operational research and artificial intelligence techniques: A survey. European journal of operational research, 204(2), 189-198. https://doi.org/10.1016/j.ejor.2009.08.003

Galant, A., \& Cadez, S. (2017). Corporate social responsibility and financial performance relationship: a review of measurement approaches. Economic research-Ekonomska istraživanja, 30(1), 676-693. https://doi.org/10.1080/1331677X.2017.1313122

Genedy, A., \& Sakr, A. (2017). The relationship between Corporate Social Responsibility and Corporate Financial Performance in developing countries. Case of Egypt. International Journal of Business and Economic Development (IJBED), 5(2).

Ghana Statistical Service (GSS, 2014).

Ghosh, A. (2015). Banking-industry specific and regional economic determinants of non-performing loans Evidence from US states. Journal of Financial Stability, 20, 93-104. https://doi.org/10.1016/j.jfs.2015.08.004

Hasan, M. S. A., Manurung, A. H., \& Usman, B. (2020). Determinants of Bank Profitability with Size as Moderating Variable. Journal of Applied Finance and Banking, 10(3), 153-166.

Hawn, O., Chatterji, A. K., \& Mitchell, W. (2018). Do investors actually value sustainability? New evidence from investor reactions to the Dow Jones Sustainability Index (DJSI). Strategic Management Journal, 39(4), 949-976. https://doi.org/10.1002/smj.2752

Inoue, Y., Kent, A., \& Lee, S. (2011). CSR and the bottom line: Analyzing the link between CSR and financial performance for professional teams. Journal of Sport Management, 25(6), 531-549.

https://doi.org/10.1123/jsm.25.6.531 
Khrawish, H. A., \& Al-Sa'di, N. M. (2011). The impact of e-banking on bank profitability: Evidence from Jordan. Middle Eastern Finance and Economics, 13(1), 142-158.

Lai, K. P. (2020). The Dis/Re-Intermediation of Finance? The Routledge Handbook of Financial Geography, 440. https://doi.org/10.4324/9781351119061-24

Lins, K. V., Servaes, H., \& Tamayo, A. (2017). Social Capital, Trust, and Firm Performance: The Value of Corporate Social Responsibility during the Financial Crisis. The Journal of Finance, 72(4), 1785-1824. https://doi.org/10.1111/jofi.12505

Lorizio, M., \& Gurrieri, A. (2019). 1. CORPORATE SOCIAL RESPONSIBILITY OVER TIME. Corporate social responsability and firms, 9.

Maon, F., Lindgreen, A., \& Swaen, V. (2009). Designing and implementing corporate social responsibility: An integrative framework grounded in theory and practice. Journal of Business Ethics, 87(1), 71-89. https://doi.org/10.1007/s10551-008-9804-2

Maqbool, S., \& Zameer, M. N. (2018). Corporate social responsibility and financial performance: An empirical analysis of Indian banks. Future Business Journal, 4(1), 84-93. https://doi.org/10.1016/j.fbj.2017.12.002

Musaji, S., Schulze, W. S., \& De Castro, J. O. (2019). How Long Does It Take to "Get to" the Learning Curve? Academy of Management Journal. https://doi.org/10.5465/amj.2017.1145

Naseem, T., Shahzad, F., Asim, G. A., Rehman, I. U., \& Nawaz, F. (2019). Corporate social responsibility engagement and firm performance in Asia Pacific: The role of enterprise risk management. Corporate Social Responsibility and Environmental Management. https://doi.org/10.1002/csr.1815

Nguyen, H. D. H., \& Dang, V. D. (2020). Bank-specific determinants of loan growth in Vietnam: evidence from the CAMELS approach. The Journal of Asian Finance, Economics, and Business, 7(9), 179-189. https://doi.org/10.13106/jafeb.2020.vol7.no9.179

Ojo, O. (2008). Appraisal of the practice of social responsibility by business organizations in Nigeria. LESIJ-Lex ET Scientia International Journal, 15(1), 155-165.

Pepper, A., \& Gore, J. (2015). Behavioral agency theory: New foundations for theorizing about executive compensation. Journal of management, 41(4), 1045-1068. https://doi.org/10.1177/0149206312461054

Saeidi, S. P., Sofian, S., Saeidi, P., Saeidi, S. P., \& Saaeidi, S. A. (2015). How does corporate social responsibility contribute to firm financial performance? The mediating role of competitive advantage, reputation, and customer satisfaction. Journal of business research, 68(2), 341-350. https://doi.org/10.1016/j.jbusres.2014.06.024

Sharma, E. (2019). A review of corporate social responsibility in developed and developing nations. Corporate Social Responsibility and Environmental Management, 26(4), 712-720. https://doi.org/10.1002/csr.1739

Shen, L., Govindan, K., \& Shankar, M. (2015). Evaluation of Barriers of Corporate Social Responsibility Using an Analytical Hierarchy Process under a Fuzzy Environment-A Textile Case. Sustainability, 7(3), 3493-3514. https://doi.org/10.3390/su7033493

Silva, T. C., Tabak, B. M., Cajueiro, D. O., \& Dias, M. V. B. (2017). A comparison of DEA and SFA using micro-and macro-level perspectives: Efficiency of Chinese local banks. Physica A: Statistical Mechanics and its Applications, 469, 216-223. https://doi.org/10.1016/j.physa.2016.11.041

Tesfai, A. (2015). Evaluating the Relationship Between Liquidity, Capital Adequacy and Non-Performing Loans on Financial Performance: Case Study of Habib Bank Ag Zurich. Unpublished Research Project Report Submitted to the Chandaria School of Business, United States International University.

Tower, L. E., \& Alkadry, M. G. (2008). The Social Costs of Career Success for Women. Review of Public Personnel Administration, 28(2), 144-165. https://doi.org/10.1177/0734371X08315343

Uwalomwa, U., \& Egbide, B. (2012). Corporate Social Responsibility Disclosures in Nigeria: A study of Listed Financial and Non-Financial Firms. Journal of Management and Sustainability, 2(1) 160-169. https://doi.org/10.5539/jms.v2n1p160

Wang, Q., Dou, J., \& Jia, S. (2016). A meta-analytic review of corporate social responsibility and corporate financial performance: The moderating effect of contextual factors. Business \& Society, 55(8), 1083-1121. https://doi.org/10.1177/0007650315584317 
Waqas, M., Fatima, N., Khan, A., \& Arif, M. (2017). Determinants of Non-performing Loans. International Journal of Finance \& Banking Studies (2147-4486), 6(1), 51-68. https://doi.org/10.20525/ijfbs.v6i1.617

Werther Jr, W. B., \& Chandler, D. (2010). Strategic corporate social responsibility: Stakeholders in a global environment. Sage.

Xie, J., Nozawa, W., Yagi, M., Fujii, H., \& Managi, S. (2019). Do environmental, social, and governance activities improve corporate financial performance? Business Strategy and the Environment, 28(2), $286-300$. https://doi.org/10.1002/bse.2224

\section{Copyrights}

Copyright for this article is retained by the author(s), with first publication rights granted to the journal.

This is an open-access article distributed under the terms and conditions of the Creative Commons Attribution license (http://creativecommons.org/licenses/by/4.0/). 